\title{
Adam Ostrowski
}

Pomeranian University in Słupsk, Poland

ORCID: 0000-0003-3455-5963

adam.ostrowski@apsl.edu.pl

\section{The Chair of Administration Science and Administrative Law at the Faculty of Law and Economics at the University of Poznań in the Interwar Period: Organization and Main Research and Teaching Directions}

\author{
Katedra Nauki Administracji i Prawa Administracyjnego Wydziału \\ Prawno-Ekonomicznego Uniwersytetu Poznańskiego w okresie \\ dwudziestolecia międzywojennego. Organizacja i główne kierunki \\ badawczo-dydaktyczne
}

\begin{abstract}
The aim of the article is to analyse source materials related to the functioning of the Chair of Administration Science and Administrative Law at the University of Poznan. The study discusses the problems experienced by the then-contemporary scientific and lecturing staff, and also characterised the atypical structure of the Faculty of Law and Economics, as composed of the sections of state law and economy. The organization of the chairs of administrative law at the University of Poznan was separated and their main research and development directions and the most important representatives were indicated. The article broadly discusses the issue of teaching administrative law in comparison to other chairs of the University of Poznan, so that the conclusions give the best possible image of the discussed subject.
\end{abstract}

Keywords: administrative law; interwar period; Faculty of Law and Economics; University of Poznań; teaching administrative law

CORRESPONDENCE ADDRESS: Adam Ostrowski, MSc in Law, Assistant, Pomeranian University in Słupsk, Arciszewskiego 22A, 76-200 Słupsk, Poland. 


\section{INTRODUCTION}

The University of Poznań was founded at a unique time - at a time, when the Organisational Committee of the University of Poznań called its first meeting on 11 November 1918 as chaired by Heliodor Święcicki. ${ }^{1}$ All this paved the way towards the opening of the University of Poznan not even a year later, on 7 May 1919, with the Faculty of Law and Economics being inaugurated just a month later (1 April 1919 being deemed to be its date of establishment). ${ }^{2}$ Beside the organiser, the subject Committee also included Józef Kostrzewski, Stanisław Kozierowski and Michał Sobeski. ${ }^{3}$ The first Dean of the Faculty, and at the same time the person who bore the brunt of organising this body, was Antoni Peretiatkowicz, ${ }^{4}$ whose scientific research clearly focused on the philosophy of law; he was also the first Head of the seminar on the theory of state. ${ }^{5}$

${ }^{1}$ Heliodor Święcicki later became the main representative of the Faculty of Medicine that was formed shortly after the formation of the Faculty of Law and Economics. See M. Musielak, Heliodor Święcicki (1854-1923), Poznań 2013.

${ }^{2}$ K. Krasowski, Zarys dziejów Wydziatu Prawa Uniwersytetu w Poznaniu w latach 1919-2004, Poznań 2004, p. 11. The University of Poznań was, beside the University of Warsaw, Stefan Batory University in Vilnius, the Jan Kazimierz University in Lviv, the Jagiellonian University in Kraków and, later, the Catholic University of Lublin (later, as the University only became a state institution in the year 1938), one of the six state universities in the Republic of Poland. Faculties of law existed at all these scientific facilities, with chairs of administrative law also in existence. The activity of the Faculty of Law and Administration was based on a unique concept of bidirectional teaching, i.e. besides the seminar of law, it also included a seminar of state economy. This name was transformed as the concept of the Faculty evolved, from the Faculty of Law, through the Faculty of Law and Economics and Political Science, until it was given the name that remained throughout the interwar period, the Faculty of Law and Economics. See Regulation of the Ministry of Religious Denominations and Public Education on legal acts made by the University of Poznań, effective from the date of its establishment on 3 August 1920 (Official Journal of the Polish Ministry of Religious Denominations and Enlightenment 1920, no. 23, item 152). The University was a state institution, however, it should be remembered that on the day of its opening, the Act on Academic Education was not yet in force, therefore it had to be considered on the basis of the provisions of the previous authority. See J. Hubert, Ogólne stanowisko prawne Uniwersytetu Poznańskiego, Poznań 1925, pp. 42-44.

${ }^{3}$ G. Labuda, Uniwersytet Poznański w latach 1919-1969, Poznań 1969, p. 5. It was already decided during the first meeting of the Organisational Committee that the Faculty of Philology needed to be established, and the Faculty of Law and the Faculty of Medicine were also considered.

${ }^{4}$ In its beginnings, the Faculty primarily struggled with problems of a staff nature, in truth, the year 1919 was a period of recruiting employees for all state universities and competition in this area was felt by the then-contemporary deans and founders of faculties of law. Professor Peretiatkowicz also had to deal with the efficient development of the curriculum and study plan as well as the analysis of the Faculty concept. See A. Gulczyński, Antoni Peretiatkowicz. Redaktor Naczelny 1921-1939, "Ruch Prawniczy, Ekonomiczny i Socjologiczny" 2006, no. 2, pp. 69-72.

5 Archiwum Uniwersytetu Adama Mickiewicza w Poznaniu (AUAM), mszp., 15/522, Wykaz seminariów, Wydział Prawno-Ekonomiczny. Sprawozdanie Dziekana za lata 1928-1929, [no page numbers]. Beside Professor Peretiatkowicz, the newly-founded Faculty also included: Zygmunt Lisowski (Roman law, Rector of the University of Poznań in 1923-1924), Jan Rutkowski (economic history), Tadeusz Brzeski (economy). 


\section{THE ESTABLISHMENT OF THE FACULTY OF LAW AND ECONOMICS AND THE FIRST YEARS OF ITS FUNCTIONING}

The number of students of the Faculty of Law and Economics of the University of Poznań rose year after year. In the year of establishment, the number hovered around one thousand, with subsequent years bringing further rises. This fact indicates that the region needed a university teaching law. ${ }^{6}$

Table 1. Number of students of the Faculty of Law and Economics in the 1928/1929 academic year

\begin{tabular}{|l|c|c|c|c|c|}
\hline \multicolumn{1}{|c|}{ Section } & First-year & Second-year & Third-year & Fourth-year & Total \\
\hline Law & 113 & 175 & 320 & 122 & 730 \\
\hline State economy & 200 & 66 & 48 & 40 & 354 \\
\hline Two sections & 278 & 45 & - & - & 323 \\
\hline Total & 591 & 286 & 368 & 162 & 1407 \\
\hline
\end{tabular}

Source: own elaboration based on: AUAM, mszp., 15/522, Statystyka Studentów Wydziału Prawno-Ekonomicznego za rok akademicki 1928/29, Wydział Prawno-Ekonomiczny, Sprawozdanie dziekana za lata 1928-1929, [no page numbers].

Attempts to promote the University of Poznań, made by professors Święcicki, Brzeski and Lisowski, used to acquire qualified scientific staff, brought results. Already in the formative years, the following persons became employees of the Faculty and greatly influenced its recognisability: Stanisław Kasznica, ${ }^{7}$ Edward Taylor, ${ }^{8}$ Alfred Ohanowicz, ${ }^{9}$ Józef Sułkowski, ${ }^{10}$ and Marcin Nadobnik. ${ }^{11}$ Besides unquestionable

${ }^{6}$ The number of students in $1930 / 1931$, as compared to $1929 / 1930$, rose by $9.9 \%$. One-third of the students of the University of Poznan were law students. A similar ratio was found at all state universities, indicating a constant need for lawyers. See Kronika Uniwersytetu Poznańskiego za lata szkolne 1929/1930 i 1930/1931 za rektoratu prof. Stanisława Kasznicy i otwarcie roku szkolnego 1931/1932 przez nowego rektora prof. Jana Sajdaka w dniu 25 października 1931 roku, Poznań 1932, p. 26 ff.

7 AUAM, mszp., 15/160/2, Teczka personalna Stanisława Kasznicy, Wykaz stanu służby, [no page numbers]. Stanisław Kasznica was the Dean of the Faculty in 1920-1921 and 1933-1936, he also headed the Chair of Administrative Sciences and Administrative law from 1920 (filling the vacancy present the moment the Faculty was founded) to 1939. He was also the Head of the Administrative Department of the Polish Ministry of Internal Affairs.

${ }^{8}$ See K. Krasowski, Zarys dziejów Wydziatu Prawa ..., p. 16. Immediately, upon his employment in 1919, Edward Taylor suggested state economy studies, he also headed the Chair of Social Economy (1923-1939) and the Chair of the Treasury and of Treasury Law (1919-1922). He became the Dean of the Faculty of Law and Economics in the 1923/1924 academic year and the Head of the Credit Union of Agricultural Companies in Kraków. See idem, Wydziat Prawno-Ekonomiczny Uniwersytetu Poznańskiego w latach 1919-1939, Poznań 2006, pp. 116-117, 138-139.

9 The then-contemporary Head of the Chair of Civil Law in 1919-1939, and the Faculty Dean in the 1924/1925 academic year. Professor Ohanowicz was also employed by the State Treasury Attorney's Office in Lviv. See ibidem, pp. 116-117.

10 Józef Sułkowski became the Dean of the Faculty in the 1926/1927 academic year and headed the Chair of Commercial and Bill Law in 1922-1939. He was also secretary of the emissary of Poland in Warsaw. See ibidem, pp. 138-139.

11 Marcin Nadobnik was the Head of the Chair of Statistics over its entire period of operation, meaning, 1920-1939 (in 1919 there was a vacancy in this position). He was also the Dean of the Faculty 
scientific careers, each of those named above-gathered experience working in managerial circles of public institutions.

Professor Edward Taylor was employed from the very beginning of existence of the Faculty of Law and Economics, and he is credited with the development of the concept of state economy studies of Poznan. This idea, as noted by the creator himself, was drawn from assumptions of education institutions in the West (e.g., the London School of Economics and Political Science or the École des Sciences Politiques). ${ }^{12}$ According to him, teaching should not rely exclusively on theory, and he described this using the following words: , , [...] it is the task of the university professor to teach students a particular course or provide them with professional knowledge. Frequent attempts are made to reduce the role of the professor to that of information provider. This is wrong. [...] In light of its enormity, progressing specialisation and variability of applications as well as their conditions, knowledge should always be acquired on one's own throughout life, but one must know where to look for it and one must have its components at their disposal. Only these are the tasks of higher education. It should, however, provide that which cannot be acquired in any other way than by special and skilful exercises and preparation, meaning, the ability to think, as it is necessary to apply the knowledge in practice". ${ }^{13}$

The Faculty of Law and Economics was composed of larger (over 100 students) and smaller (below 100 students) institutes. Large institutes were: the institute of history of the law of Western Europe, science of administration and administrative law, civil law I, economy I, canonical law as well as theory and philosophy of law. ${ }^{14}$ Those numbering less than 100 participants included: criminological sciences, economic geography, fiscal affairs, Roman law, statistics, civil law II, theory of state, economic history, civil procedure, business law, economy II, history of Polish law and international law.

of Law and Economics in the 1925-1926 academic year. The Professor was also the Head of the Budget Department at the Polish Ministry of the Former Prussian Province. See ibidem, pp. 138-139.

12 Ibidem, p. 107. See also A. Lityńska, Działalność naukowa i publicystyczna Edwarda Taylora, "Ruch Prawniczy, Ekonomiczny i Socjologiczny" 1985, no. 47(2), pp. 343-356.

13 E. Taylor, Twórczość naukowa Adam Krzyżanowskiego, "Ruch Prawniczy i Ekonomiczny" 1958, no. 20(3), p. 99.

${ }_{14}$ AUAM, mszp., 15/80, Wykaz zakładów Wydziału Prawno-Ekonomicznego w roku akademickim 1935/1936, Zakłady Wydziału Prawno-Ekonomicznego UP, [no page numbers]. 


\section{THE CHAIRS OF ADMINISTRATIVE LAW OF THE UNIVERSITY OF POZNAŃ: STRUCTURE, DEVELOPMENT AND RESEARCH FIELDS}

The Chair of Administrative Law did not have a single homebody. There existed the Chair of Administrative Sciences and Administrative Law I at the Faculty of Law and Economics (headed by Professor Stanisław Kasznica ${ }^{15}$ ), and the Chair of Administrative Sciences and Administrative Law II (the heads in a very small temporal period were Professor Bohdan Wasiutyński and Professor Marian Zimmermann). Inasmuch as the former operated without trouble, the operation of the latter was suspended in 1933-1938. ${ }^{16}$

Due to intense burden in the teaching process, which was directly related to the subdivision of studies into the state law and state economy sections, it was necessary to operate two chairs: the Chair of Administrative Sciences and the Chair of Administrative Law. Arguments in favour included the fact that the course plan for the state law institute foresaw 150 hours of lectures in administrative sciences and administrative law (in the final, fourth year). ${ }^{17}$ After the law study reform of 1939, the course in administrative law was divided across the third (administration part I - 90 hours of lectures) and fourth year (administration part II - 80 hours of lectures and 60 hours of obligatory tutorials).${ }^{18}$ However, the course in state economy, also established at the Faculty of Law and Economics, due to the practical needs of students, planned for a staggering 300 hours of obligatory lectures in administrative sciences and administrative law. ${ }^{19}$

In 1933, along with the closure of other chairs and due to a temporary vacancy (in the years 1925-1932 the deputy head was held by Julian Hubert, ${ }^{20}$ and in the

${ }^{15}$ Even before Professor Stanisław Kasznica took up his post, lectures on administrative law in the winter semester were given by Konrad Kolszewski, who later became the President of the Court of Appeal in Poznań. See R. Budzinowski, J. Haberko, K. Kokocińska, M. Materniak-Pawłowska, T. Nieborak, Myśląc o przyszłości, nie zapominajmy o przeszłości, Poznań 2019, p. 187.

16 AUAM, mszp., 15/531, Pismo dziekana Wydziału Prawno-Ekonomicznego Bohdana Winiarskiego do Ministerstwa Wyznań Religijnych i Oświecenia Publicznego w sprawie przywrócenia II Katedry Prawa Administracyjnego z dnia 26 stycznia 1938 roku, Starania w Ministerstwie WRiOP o przywrócenie II Katedry Prawa Administracyjnego, [no page numbers].

17 AUAM, mszp., 15/523, Rozkład godzin wykładów według propozycji Rady Wydziałowej Uniwersytetu Poznańskiego, Reforma studiów prawnych, p. 12.

18 AUAM, mszp., 15/523, Projekt rozkładu materiału nauki na wydziałach prawa, Reforma studiów prawnych, [no page numbers].

19 AUAM, mszp., 15/531, Pismo ku pamięci Jaśnie Wielmożnego Pana Senatora Chrzanowskiego z dnia 12 lipca 1938 roku, Starania w Ministerstwie WRiOP o przywrócenie II Katedry Prawa Administracyjnego, [no page numbers].

${ }^{20}$ Besides his scientific activity at the University of Poznań, Julian Hubert was also a member of the Editorial Staff of "Przegląd Administracyjny" ("Administrative Review") and "Ruch Prawniczo-Ekonomiczny" ("Legal and Economic Movement"). During the uprisings in Silesia, he was ordered to organise administration in Silesia, and in 1922-1934 he was a member of the Polish 
years 1924-1933 this position was not filled at all ${ }^{21}$ ) of the head of the Chair of Administration Science and Administrative Law II - which, as it turned out, became an argument of the Ministry of Religious Denominations and Enlightenment - it was decided to liquidate this unit.22 This action was followed by a noticeable decline in teaching quality, as lectures started to be held to an incomplete extent (correspondence shows that these classes were "contracted hours") ${ }^{23}$ and, as they confessed, without proper knowledge of the subject matter. These facts, along with the suggestion that the reactivated chair should be taken over by doc. $\mathrm{dr}$ Tadeusz Bigo ${ }^{24}$ of the Jan Kazimierz University in Lviv, constituted reasoning of the management of the Faculty of Law and Economics in favour of reactivation of the Chair of Administrative Sciences and Administrative Law II. ${ }^{25}$ The Faculty

delegation to negotiate with Germany and the Free City of Danzig on liquidation, local government, adjustment and financial affairs. He became a practicing attorney after 1945. See A. Woźnicki, Wywiad $z$ adwokatem drem Julianem Hubertem, "Palestra" 1973, no 12, p. 3.

${ }^{21}$ R. Budzinowski, J. Haberko, K. Kokocińska, M. Materniak-Pawłowska, T. Nieborak, op. cit., p. 187.

${ }^{22}$ By the power of the new Polish Act of 15 March 1933 on academic schools, the Minister of Religious Denominations and Public Enlightenment could wind down chairs after acquiring a non-binding opinion of Faculty Councils, which only provided its opinion. The subject act of law, due to its liberal provisions in terms of control of the activity of the minister, was a grave threat to the faculties operating at that time. See Act of 15 March 1933 on academic schools (Journal of Laws 1933, no. 29, item 247).

${ }^{23}$ AUAM, mszp., 15/531, Pismo ku pamięci Jaśnie Wielmożnego Pana Senatora Chrzanowskiego z dnia 12 lipca 1938 roku, Starania w Ministerstwie WRiOP o przywrócenie II Katedry Prawa Administracyjnego, [no page numbers].

24 Tadeusz Bigo (1894-1975) was a professor at the Faculty of Law and Political Skills of the Jan Kazimierz University in Lviv and made history by creating the concept of local government operating as a corporation, i.e. provided by law with a legal personality. These terms became more or less the basis of the functioning of the local government in the Third Polish Republic. The debate of the already mentioned Jerzy Panejko with Tadeusz Bigo in the context of local government become one of the most broadly known discussions between theorists of local government of the interwar period. Tadeusz Bigo also debated employment at the Stefan Batory University in Vilnius with Jerzy Panejko. Analyses conducted by the Council of the Faculty of Law and Social Sciences of the University in Vilnius ended with Tadeusz Bigo and Tadeusz Hilarowicz being rejected as candidates, with Jerzy Panejko being chosen instead. See P. Żukowski, Tadeusz Antoni Bigo (1894-1975): droga na katedrę uniwersytecka we Wrockawiu, "Folia Iuridica Universitatis Wratislaviensis" 2015, vol. 4(1), pp. 9-49; M. Miemiec, Zakład prawa administracyjnego. Historia i wspótczesność, "Przegląd Prawa i Administracji” 2015, vol. 100, pp. 193-197; J. Kordeczuk, Dzieje Zakładu Powszechnej Historii Państwa i Prawa Uniwersytetu Wrocławskiego, "Przegląd Prawa i Administracji” 2015, vol. 100, pp. 51-52. Tadeusz Bigo was nominated to become a professor in October 1945 at the University of Wrocław, where he took over the Chair of Administrative Sciences and Administrative Law. He was also the Dean of the Faculty of Law and Administration of the University of Wrocław for several years. See K. Jonca, Wydziat Prawa i Administracji Uniwersytetu Wrocławskiego 1945-1995, Wrocław 1996, pp. 17-23.

${ }^{25}$ AUAM, mszp., 15/531, Pismo ku pamięci Jaśnie Wielmożnego Pana Senatora Chrzanowskiego z dnia 12 lipca 1938 roku, Starania w Ministerstwie WRiOP o przywrócenie II Katedry Prawa Administracyjnego, [no page numbers]. 
management also argumented in favour of reestablishing the Chair with the fact that it would not be possible to properly implement the curriculum assumed and approved by the Polish Ministry of Religious Denominations and Enlightenment without it. ${ }^{26} \mathrm{After}$ a period of a hard and long-term effort, the Chair of Administrative Sciences and Administrative Law II was reestablished in 1938 year, ${ }^{27}$ while on 20 April 1939 the management was officially taken over with leadership by Professor Marian Zimmermann ${ }^{28}$ and Bohdan Winiarski as the dean, who struggled tirelessly to achieve this. ${ }^{29}$

The problem of the Chair of Administrative Sciences and Administrative Law II mentioned above, of the vacancy of the head, carried with itself far-reaching consequences, both at the organisational level, as well as in terms of bringing about a dispute between the Dean of the Faculty of Law and Economics and the Polish Ministry of Religious Denominations and Enlightenment. In his correspondence with the Ministry, the Faculty Dean claimed that it was insufficient to simply provide coverage for the required hours of lectures and tutorials assigned to the Chair. He confronted the duties of lecturer, who had to exclusively teach his assigned volume of lecture hours, with the scientific and official duties of deputy professor, as motioned for starkly by the Dean's Office. ${ }^{30}$ He practically bore the same duties as the chair professor, hence, besides his lectures, he also needed to hold seminars, tutorials, both in scientific and administrative terms. The deputy professor was also obliged to participate in university committee meetings as required by the university management. The Dean's Office of the Faculty of Law and Economics, in correspondence with the Ministry, stressed the clear division between contract hours and being the deputy professor at the chair as found in the

${ }^{26}$ AUAM, mszp., 15/531, Pismo dziekana Wydziału Prawno-Ekonomicznego Bohdana Winiarskiego do Ministerstwa Wyznań Religijnych i Oświecenia Publicznego w sprawie przywrócenia II Katedry Prawa Administracyjnego z dnia 26 stycznia 1938 roku, Starania w Ministerstwie WRiOP o przywrócenie II Katedry Prawa Administracyjnego, [no page numbers].

27 AUAM, mszp., 15/532, Rozporządzenie Ministra Wyznań Religijnych i Oświecenia Publicznego z dnia 20 lipca 1938 roku o utworzeniu i zwinięciu niektórych katedr i zakładów naukowych w szkołach akademickich, Wydział Prawa: Reorganizacja Wydziału, p. 1.

${ }^{28}$ It is worth mentioning here that while in the interwar period Professor Marian Zimmermann could not have a significant impact on the academic potential of the Chair, from 1945 until his death in 1969 he made a significant contribution to the shape of the Code of Administrative Procedure, as well as to the development of the didactic aspect of administrative law through the creation of several highly regarded textbooks. See R. Budzinowski, J. Haberko, K. Kokocińska, M. Materniak-Pawłowska, T. Nieborak, op. cit., p. 191.

29 See J. Sandorski, Bohdan Winiarski-prawo, polityka, sprawiedliwość, Poznań 2004.

30 AUAM, mszp., 15/533, Pismo Dziekana Wydziału Prawno-Ekonomicznego Uniwersytetu Poznańskiego do Ministerstwa Wyznań Religijnych i Oświecenia Publicznego w sprawie zastępstwa Katedry Nauki Administracji i Prawa Administracyjnego z dnia 9 lutego 1925 roku, Wydział Prawno-Ekonomiczny. Poufne [1924-1928, 1937], [no page numbers]. 
Polish Act of 9 October $1923^{31}$ and the Regulation of the Polish Cabinet of Ministers of 3 March $1924^{32}$ issued on its basis, indicating the difference between the two categories of the positions at hand. The vacancy in the position of deputy professor of the chair was significant from the point of view of steady operation both of the legal as well as the state economy seminars, as it prevented final exams from being held, in effect creating a group of several dozens of graduates prevented from obtaining their studies graduation diplomas. ${ }^{33}$ The above problem was successfully overcome, ending the tenure of Professor Julian Hubert as deputy professor in the years 1925-1932.

The Faculty of Law and Economics also struggled to employ Bohdan Wasiutyński, at that time already a distinguished specialist in administration, as an associate professor. The arguments in favour of the above were similar to the ones used in the case Julian Hubert, i.e. material support of the seminar of state economy. Precisely two years after the opening of the University of Poznan, Bohdan Wasiutyński gave in to the pressure by the Faculty of Law and Economics (7 May 1921), however, with the pressure by the University of Warsaw not waning, he moved there four years later, in $1925 .{ }^{34}$

Even if the operation of the Chair of Administrative Sciences and Administrative Law II was accompanied by a great deal of uncertainty and instability as to its existence that could be the subject of much more work, the pillar of the state law seminar in the context of administrative law was the Chair of Administrative Sciences and Administrative Law I. Throughout its entire existence, it was headed by Professor Stanisław Kasznica, long-time Dean of the Faculty of Law and Economics, and Rector of the University of Poznan. He developed the structure of the Chair and drove its development. The archives of the Adam Mickiewicz University

31 Act of 9 October 1923 on the salary of state officials and the army (Journal of Laws 1923, no. 116, item 924).

32 Regulation of the Council of Ministers of 3 March 1924 to Article 28 of the Act of 9 October 1923 on the salary of state officials and the army, regarding the remuneration of deputy professors of academic schools (Journal of Laws 1924, no. 31, item 311).

33 AUAM, mszp., 15/533, Pismo Dziekana Wydziału Prawno-Ekonomicznego Uniwersytetu Poznańskiego do Ministerstwa Wyznań Religijnych i Oświecenia Publicznego w sprawie zastępstwa Katedry Nauki Administracji i Prawa Administracyjnego z dnia 9 lutego 1925 roku, Wydział Prawno-Ekonomiczny. Poufne [1924-1928, 1937], [no page numbers].

${ }^{34}$ K. Krasowski, Wydziat Prawno-Ekonomiczny..., pp. 124-125. See also H. Izdebski, Bohdan Wasiutyński 1882-1940, "Samorząd Terytorialny" 1991, no. 5, p. 41 ff. He was nominated associate professor of the University of Warsaw in 1923 already, and lectures at the University of Poznań were contracted ones. At this point it is worth emphasising that Bohdan Wasiutyński, given his reluctance to remain in Poznań, clearly cannot be regarded as the foundation of the position of administrative sciences in this scientific centre. See also R. Budzinowski, J. Haberko, K. Kokocińska, M. Materniak-Pawłowska, T. Nieborak, op. cit., p. 187. 
of Poznań hide a plethora ${ }^{35}$ of correspondence between him and the state authorities, on whom both the existence of the University as well as of the Faculty or Chair depended. It is worth noting that the numbers of scientific employees specialising in administrative law at the Faculty did not overfill the Chair, as was the nature of the then-contemporary scientific facilities.

With his broad experience in state administration as Concept Officer of the Viceroyship or the Section Head (Director) of the Administrative Department at the Polish Ministry of the Interior, ${ }^{36}$ he was an authority for the university members. The development of textbooks for future lawyers by the professor ${ }^{37}$ described the research profile of the Chair of Administrative Sciences and Administrative Law I that he headed. Stanisław Kasznica, in addition to his fast-paced academic career, was also thriving in a professional context. Apart from the above-mentioned positions, he was an expert on the "autonomous statute" for eastern Lesser Poland (Pol. Matopolska), or a senator in the 1922-1927 term. ${ }^{38}$

The main research fields taken on by the Chair of Administrative Sciences and Administrative Law were, besides the main subject taught, administrative law as well: economic, social or local government law. The fact of dealing with the branches in question was determined by the current socio-political context, i.e. the lack of, or rudimentary regulation of these issues. The expression of such a research direction was supported by the work of the already mentioned long-time Head of the Chair - Stanisław Kasznica. The order of the subject entailed a transition from introductory definitions of administrative law, branches of the administration and sources of administrative law. The scope of teaching encompassed an analysis of public administration bodies (entities such as offices, governmental power, local government, public plants and enterprises, public civic servants and public officials), administrative acts together with administrative procedure, as well as administrative penalties and control of administration. ${ }^{39}$ In his work, Stanisław Kasznica strove not to debate others' perceptions of the subject matter, presenting solely what he himself achieved or believed to be most accurate.

${ }^{35}$ In view of the fact that the vast majority of the archives deposited in the Adam Mickiewicz University Archives in Poznań have been destroyed.

${ }^{36}$ AUAM, mszp., 15/160/2, Teczka personalna Stanisława Kasznicy, Wykaz stanu służby, [no page numbers].

37 Such as: Nauka administracji, parts 1-2; Polskie prawo administracyjne. Notatki z wyktadów prof. St. Kasznicy z r. 1928/1929; Teoria samorzadu. Wyktady prof. St. Kasznicy z r. 1935/1936; Samorzą. Skrypt z wyktadów prof. St. Kasznicy, parts 1-2; Polskie prawo administracyjne: pojęcia i instytucje zasadnicze; Prawo administracyjne - przeglad prawodawstwa.

${ }^{38}$ R. Budzinowski, J. Haberko, K. Kokocińska, M. Materniak-Pawłowska, T. Nieborak, op. cit., p. 188.

39 A comprehensive textbook on Polish administrative law was only published during the German occupation in 1943. At that time, Stanisław Kasznica was hiding under the pseudonym Dr. A. Łużycki. See S. Kasznica, Polskie prawo administracyjne, Poznań 1943. 
Due to its research interests, the operation of the Chair of Administrative Sciences and Administrative Law was also based on a theory of local government. ${ }^{40}$ Professor Kasznica described in detail the fundamental terms such as: differentiation between centralisation and decentralisation of power, entities of local government, on the basis of corporations and their subdivision, or plants and enterprises of public use (non-profit), as well as oversight of local government. ${ }^{41}$ Moreover, in his deliberations on self-government, Stanisław Kasznica juxtaposed rural self-government with urban and district self-government from before the introduction of the 1933 Act on Self-Government, where self-government units divided into voivodeship areas (central, western, eastern and southern) $)^{42}$ were analysed. These comparisons were confronted with the reality of the time after the introduction of the above mentioned Act. In his analyses of the core of local government, he would frequently return to the core of guarantee of independence, as well as the way decentralisation was important for the coexistence of citizens in state.

\section{THE INFLUENCE OF THE ACTIVITIES OF THE CHAIR OF ADMINISTRATIVE LAW OF THE UNIVERSITY OF POZNAŃ FROM THE INTERWAR PERIOD ON REALITY AFTER 1939}

After the German army entered Poznan, ${ }^{43}$ Stanisław Kasznica was moved to the south of the country, ${ }^{44}$ and from 1942 onwards he remained in Warsaw, where he held secret lectures as part of the University of Western Lands ${ }^{45}$ and the University of Warsaw, allowing him to stay in touch with teaching and administrative law. At

${ }^{40}$ This was also the title of the lectures by Professor Kasznica published by the Lawyers' and Economists' Club of the Students' Association of the University of Poznan.

${ }^{41}$ S. Kasznica, Teoria samorzadu, Poznań 1936.

42 Idem, Skrypt wedtug wykładów prof. dr Kasznicy. Cz. 1, nakładem i w powielarni Koła Prawników i Ekonomistów 1935, pp. 2-9.

${ }^{43}$ He continued to participate actively in its existence after 1 September 1939 as the Dean of the Faculty of Law and Economics. On that day he signed Deans' certificates at the Dean's Office, later participating in a meeting of the Scientific Council of the University of Poznań, after which meeting the Collegium Minus was sealed by the Gestapo, and the operations of the Faculty were lawlessly interrupted. This was the end of the enormous contributions of Professor Kasznica for the Faculty of Law and Economics. See K. Krasowski, Zarys dziejów Wydziału Prawa..., p. 81.

${ }^{44}$ He settled in Limanowa, where he remained until 1942. See S. Kasznica, Autobiografia, do druku przygotowata i opatrzyła wstępem Eleonora Kasznica, "Analecta" 1995, no. 1, p. 224.

45 This university was founded on 24 November 1940 by an initiative of a group of professors of the University of Poznań. First Rector was Professor Ludwik Jaxa-Bykowski (until 1942), followed, until liberation, by Professor Roman Pollak. The university numbered ca. 2000 people, with ca. 300 academic lecturers. The Faculty of Law was one of the best developed and most lively among those units. See G. Labuda, op. cit., pp. 16-17. 
this time, he also published the already mentioned textbook for future specialists in administrative law. ${ }^{46}$

The history of the Chair of Administrative Sciences and Administrative Law was not just a pattern of endless successes in science and teaching. This was, naturally, not a single case in the preceding period of history, as almost every chair of administrative law in Poland struggled to continue existing. Still, respect must be paid to the people mentioned in this paper, after all, it is thanks to them that administrative law was taught at all at the University of Poznań. The persistence and efforts of such personalities as Stanisław Kasznica, or episodically also Bohdan Wasiutyński and Marian Zimmermann, ensured the unwavering work of these teaching centres. Besides, they undoubtedly also influenced the characteristics of the research profile, both of the Chair of Science of Administration and Administrative Law, and of legal sciences not only in Greater Poland (Pol. Wielkopolska), but also in general.

Learning administrative law in the interbellum provided the foundation for a broad range of institutions that exist contemporaneously. ${ }^{47}$ The current management of the Faculty of Law and Administration of the Adam Mickiewicz University of Poznan honour the memory of the employees of the discussed chair, a fact that seems to be the best realisation of the influence of science of the years 1918-1939 on contemporary times, ${ }^{48}$ remembering those who a century ago created and sounded the rhythm of development of their currently very valued research and development facility.

\section{REFERENCES}

\section{Archives}

Archives of Adam Mickiewicz University in Poznań, ref. no. 15.

\section{Literature}

Budzinowski R., Haberko J., Kokocińska K., Materniak-Pawłowska M., Nieborak T., Myślac o przyszłości, nie zapominajmy o przeszłości, Poznań 2019.

Gulczyński A., Antoni Peretiatkowicz. Redaktor Naczelny 1921-1939, "Ruch Prawniczy, Ekonomiczny i Socjologiczny" 2006, no. 2.

46 S. Kasznica, Polskie prawo administracyjne, Poznań 1943.

${ }^{47}$ In the discussed case of the Chairs of Administrative Law at the University of Poznan, this may be, i.a., the heritage in the form of the mentioned textbook by S. Kasznica Polskie prawo administracyjne, as well as the following works: A. Peretiatkowicz, Podstawowe pojęcia prawa administracyjnego, Poznań 1946; B. Wasiutyński, Ustrój władz administracyjnych, państwowych i samorządowych, Poznań 1929.

${ }^{48}$ For example, the Pallottine Church in Poznan saw in the year 2014 a mass to commemorate the $55^{\text {th }}$ anniversary of the death of Stanisław Kasznica. See M. Zaradniak, Stanisław Kasznica - uczony i patriota. Mija 55 lat od jego śmierci, 17.11.2013, https://gloswielkopolski.pl/stanislaw-kasznica-uczony-i-patriota-mija-55-lat-od-jego-smierci/ar/1042661 [access: 21.09.2020]. 
Hubert J., Ogólne stanowisko prawne Uniwersytetu Poznańskiego, Poznań 1925.

Izdebski H., Bohdan Wasiutyński 1882-1940, "Samorząd Terytorialny” 1991, no. 5.

Jonca K., Wydział Prawa i Administracji Uniwersytetu Wrocławskiego 1945-1995, Wrocław 1996.

Kasznica S., Autobiografia, do druku przygotowała i opatrzyła wstepem Eleonora Kasznica, "Analecta" 1995 , no. 1.

Kasznica S., Nauka administracji, parts 1-2, Poznań 1933.

Kasznica S., Polskie prawo administracyjne, Poznań 1943.

Kasznica S., Skrypt według wykładów prof. dr Kasznicy. Cz. 1, nakładem i w powielarni Koła Prawników i Ekonomistów 1935.

Kasznica S., Teoria samorzadu, Poznań 1936.

Kordeczuk J., Dzieje Zakładu Powszechnej Historii Państwa i Prawa Uniwersytetu Wrocławskiego, "Przegląd Prawa i Administracji” 2015, vol. 100.

Krasowski K., Wydziat Prawno-Ekonomiczny Uniwersytetu Poznańskiego w latach 1919-1939, Poznań 2006.

Krasowski K., Zarys dziejów Wydzialu Prawa Uniwersytetu w Poznaniu w latach 1919-2004, Poznań 2004.

Kronika Uniwersytetu Poznańskiego za lata szkolne 1929/1930 i 1930/1931 za rektoratu prof. Stanistawa Kasznicy i otwarcie roku szkolnego 1931/1932 przez nowego rektora prof. Jana Sajdaka w dniu 25 października 1931 roku, Poznań 1932.

Labuda G., Uniwersytet Poznański w latach 1919-1969, Poznań 1969.

Lityńska A., Działalność naukowa i publicystyczna Edwarda Taylora, "Ruch Prawniczy, Ekonomiczny i Socjologiczny" 1985, no. 47(2).

Miemiec M., Zakład prawa administracyjnego. Historia i wspótczesność, "Przegląd Prawa i Administracji” 2015, vol. 100.

Musielak M., Heliodor Święcicki (1854-1923), Poznań 2013.

Peretiatkowicz A., Podstawowe pojęcia prawa administracyjnego, Poznań 1946.

Sandorski J., Bohdan Winiarski - prawo, polityka, sprawiedliwość, Poznań 2004.

Taylor E., Twórczość naukowa Adam Krzyżanowskiego, "Ruch Prawniczy i Ekonomiczny" 1958, no. 20(3).

Wasiutyński B., Ustrój władz administracyjnych, państwowych i samorzadowych, Poznań 1929.

Woźnicki A., Wywiad z adwokatem drem Julianem Hubertem, "Palestra" 1973, no. 12.

Żukowski P., Tadeusz Antoni Bigo (1894-1975): droga na katedrę uniwersytecka we Wrocławiu, "Folia Iuridica Universitatis Wratislaviensis" 2015, vol. 4(1).

\section{Online sources}

Zaradniak M., Stanisław Kasznica - uczony i patriota. Mija 55 lat od jego śmierci, 17.11.2013, https:/gloswielkopolski.pl/stanislaw-kasznica-uczony-i-patriota-mija-55-lat-od-jego-smierci/ ar/1042661 [access: 21.09.2020].

\section{Legal acts}

Act of 9 October 1923 on the salary of state officials and the army (Journal of Laws 1923, no. 116, item 924).

Act of 15 March 1933 on academic schools (Journal of Laws 1933, no. 29, item 247).

Regulation of the Ministry of Religious Denominations and Public Education on legal acts made by the University of Poznan, effective from the date of its establishment on 3 August 1920 (Official Journal of the Polish Ministry of Religious Denominations and Enlightenment 1920, no. 23 , item 152). 
Regulation of the Council of Ministers of 3 March 1924 to Article 28 of the Act of 9 October 1923 on the salary of state officials and the army, regarding the remuneration of deputy professors of academic schools (Journal of Laws 1924, no. 31, item 311).

\begin{abstract}
ABSTRAKT
Celem artykułu jest analiza materiałów źródłowych związanych z funkcjonowaniem Katedry Nauki Administracji i Prawa Administracyjnego na Uniwersytecie Poznańskim. W opracowaniu omówiono problemy, z jakimi borykali się ówcześni pracownicy naukowo-dydaktyczni, scharakteryzowano także nietypową strukturę Wydziału Prawno-Ekonomicznego. Wyodrębniono organizację katedr prawa administracyjnego funkcjonujących na Uniwersytecie Poznańskim oraz wskazano ich główne kierunki badawczo-rozwojowe i najważniejszych przedstawicieli. W pracy szeroko umiejscowiona została pozycja nauczania prawa administracyjnego na tle innych katedr Uniwersytetu Poznańskiego, tak aby końcowe wnioski dały najlepszy obraz istoty omawianego przedmiotu.
\end{abstract}

Słowa kluczowe: prawo administracyjne; dwudziestolecie międzywojenne; wydział Prawno-Ekonomiczny; Uniwersytet Poznański; nauczanie prawa administracyjnego 